\title{
REFLEKTIF EXPERIENCE PARENTING LEARNING (REPIL) UNTUK MENINGKATKAN CARA PENGASUHAN DAN KARAKTER ANAK PADA IBU RUMAH TANGGA DI DESA PARAKAN JAYA, KABUPATEN BOGOR
}

\author{
Muhamad Rifqi Wildani, Tri Wahyuni, Andriyani Damayanti. \\ rifqieres.mohamad97@gmail.com \\ Mahasiswa Fakultas Agama Islam
}

\begin{abstract}
ABSTRAK
Dengan tingkat pendidikan yang rendah, dan angka pengangguran yang tinggi menjadi rawan akan pemasalahan sosial dan ekonomi. Permasalahan ini menjadi masalah yang perlu penyelesaian secara bersama. Baik lembaga mikro sosial masyarakat yaitu keluarga, pemerintahan dan juga anggota masyarakat. Cara pengasuhan dan lingkungan turut memberikan andil dalam menumbuh kembangkan karakter anak. Anak-anak dalam masa pengasuhan orangtua seyogyanya dapat tumbuh berkembang memiliki karakter yang baik. Begitu pula orangtua dengan pengalaman yang dimiliki dapat melakukan pengasuhan kepada anak mereka. Namun terkadang apa yang dilakukan bukan berdasarkan atas pengetahuan akan tetapi lebih kepada pengalaman yang turun temurun dari orangtuanya. Beruntung jika cara-cara yang dilakukan itu positif dan membangun.
\end{abstract}

\section{Kata Kunci: Karakter Anak, Pendidikan, Pengasuhan Orangtua.}

\section{PENDAHULUAN}

Masyarakat pedesaan dengan
tingkat pendidikan yang rendah, dan
angka pengangguran yang tinggi menjadi
rawan akan pemasalahan sosial dan
ekonomi. Permasalahan ini menjadi
masalah yang perlu penyelesaian secara
bersama. Baik lembaga mikro sosial
masyarakat yaitu keluarga, pemerintahan
dan juga anggota masyarakat. Dalam hal
ini titik tumpu penyelesaian berawal dari
keluarga. Jika setiap keluarga mampu
melakukan pengasuhan dan pedidikan
yang baik maka secara sosial dan
ekonomi masyarakat akan membaik.
Cara pengasuhan dan lingkungan
turut memberikan andil dalam
menumbuh kembangkan karakter anak.
Anak-anak dalam masa pengasuhan

Masyarakat pedesaan dengan \section{.} an 
yaitu pemukiman, pekarangan dan persawahan. Luas pemukiman yaitu seluas 1.633.550Ha, Pekarangan yaitu 177.950Ha, dan selebihnya menjadi lahan persawahan atau ladang sekitar seluas $280.000 \mathrm{Ha}$.

Secara sosial ciri masyarakat pedesaan masih melekat seperti gotong royong namun jika dilihat frekuensinya saat ini sudah mulai berkurang.

Secara ekonomi, masih termasuk masyarakat yang kurang berkembang pada tingkat ekonomi. Karena sebagian besar mata pencaharian masyarakat adalah buruh, baik buruh pabrik, buruh tani maupun buruh bangunan.

Masyarakat Desa khusunya para ibu rumah tangga memiliki jumlah $22, \& \%$ dari seluruh jumlah penduduk Desa Parakanjaya, jumlah ibu rumah tangga yaitu 2.346 jiwa. Usia anak-anak hingga remaja dengan jumlah sebagai berikut: Usia 0-6 tahun sebanyak 741 jiwa, usia 7-12 tahun 1.154 jiwa, usia 1318 tahun 1.078 jiwa. Total keseluruhan jumlah anak yaitu 28,5 \% dari total keseluruhan jumlah penduduk Desa. Artinya hampir separuh penduduk Desa yaitu terdiri dari ibu rumah tangga dan anak yang diasuh para ibu. Usia produktif perempuan 26-40 tahun berjumlah 1.479 jiwa.

Dari potensi para ibu rumah tangga dan anak yang mereka asuh, jika memiliki pendidikan dan pengasuhan yang baik, maka separuh persoalan pendidikan dapat diselesaikan. Namun demikian pengabdian ini akan memulai dengan perwakilan wilayah yang ada di desa Parakan Jaya, yang mereka merupakan para kader yang kemungkinan besar dapat menularkan kepada masyarakat melalui layanan pos pelayanan terpadu yang dikerjakan oleh kelompok Program kesejahteraan Keluarga (PKK). Luaran yang diharapkan dari kegiatan ini yaitu kelompok para ibu rumah tangga yang memiliki anak dapat melakukan pengasuhan yang menumbuhkan karakter pada anak.

\section{METODE PENGABDIAN}

Teknik yang digunakan dalam melakukan pengabdian ini yaitu pelatihan dan pendampingan. Pelatihan akan dilaksanakan dengan memberikan materi pengasuhan dan karakter melibatkan para dosen yang memiliki kemampuan di bidang pendidikan, keluarga, anak, pengasuhan dan karakter.

Teknik pengumpulan data melalui observasi, yaitu melakukan pengamatan saat berjalannya pelatihan. Menghimpun data hasil reflektif para orangtua pada saat pelatihan.

Pengumpulan data melalui wawancara digunakan untuk pendalaman hasil reflektif serta langkah-langkah orangtua dalam menyelesaikan masalah pengasuhan anak mereka melalui pendampingan.

Pengolahan data dilakukan secara kualitatif, dengan menghimpun data pengamatan, dokumen, wawancara. Kemudian memberikan kategori pada data membentuk tema, dan menarik kesimpulan 
Tahapan pekerjaan dan tujuan program sebagai berikut;

\begin{tabular}{|c|c|c|}
\hline No & Tahapan Pekerjaan & Tujuan \\
\hline 1 & $\begin{array}{lcr}\text { Melakukan } & \text { observasi wilayah } & \text { dan } \\
\text { membangun } & \text { kesepahaman } & \text { dalam } \\
\text { kerjasama pengabdian } & & \end{array}$ & $\begin{array}{lrr}\text { Untuk mendapatkan gambaran } \\
\text { masyarakat } \quad \text { sasaran } & \text { dan } \\
\text { mendapatkan legalitas } & \text { kerja } \\
\text { pengabdian di masyarakat } & \end{array}$ \\
\hline 2 & $\begin{array}{l}\text { Melakukan identifikasi sasaran pelatihan } \\
\text { yaitu ibu rumah tangga yang memiliki } \\
\text { anak balita, kanak-kanak, anak-anak, dan } \\
\text { remaja }\end{array}$ & $\begin{array}{l}\text { Untuk memudahkan melakukan } \\
\text { reflektif dan mempraktekan cara } \\
\text { pengasuhan yang bermakna bagi } \\
\text { mereka }\end{array}$ \\
\hline 3 & $\begin{array}{l}\text { Melakukan kesepakatan dengan warga } \\
\text { sasaran mengenai pelaksanaan pelatihan } \\
\text { parenting berbasis refleksi dan karakter }\end{array}$ & $\begin{array}{l}\text { Efektivitas kegiatan dengan } \\
\text { mengetahui waktu yang tersedia } \\
\text { dari mereka }\end{array}$ \\
\hline 4 & $\begin{array}{l}\text { Melakukan } \\
\text { pelatihan }\end{array}$ & $\begin{array}{l}\text { Melihat proses reflektif experience } \\
\text { parenting learning }\end{array}$ \\
\hline 5 & $\begin{array}{l}\text { Menghimpun data; } \\
\text { kekeliruan yang dilakukan dalam } \\
\text { pengasuhan }\end{array}$ & $\begin{array}{l}\text { Melihat perubahan } r \\
\text { pengambilan tindakan } \\
\text { bermakna bagi orangtua } \\
\text { pengasuhan }\end{array}$ \\
\hline & $\begin{array}{l}\text { menemukan solusi dari masalah yang } \\
\text { dihadapi } \\
\text { mengambil makna dari peristiwa yang } \\
\text { dialami }\end{array}$ & \\
\hline 6 & $\begin{array}{l}\text { Memberikan penguatan hasil pelatihan } \\
\text { pada waktu pendampingan }\end{array}$ & Pendalaman hasil temuan \\
\hline
\end{tabular}




\section{REALISASI PROGRAM}

\section{Anggaran Biaya}

Dalam pelaksanaan program pengabdian masyarakat (PKM-M) ini biaya keseluruhan yang diusulkan ke DIKTI adalah Rp. 12.500.000,00 dengan rincian sebagai berikut :

\begin{tabular}{|l|l|l|}
\hline No. & \multicolumn{1}{|c|}{ Jenis Pengeluaran } & \multicolumn{1}{c|}{ Biaya (Rp.) } \\
\hline 1. & Bahan habis pakai & Rp. 2.940.000,00 \\
\hline 2. & Peralatan Penunjang & Rp. $4.950 .000,00$ \\
\hline 3. & Perjalanan & Rp. $1.000 .000,00$ \\
\hline 4. & Lain-lain & Rp. 3.464.000,00 \\
\hline & JUMLAH & Rp. 12.354.000,00 \\
\hline
\end{tabular}

Jadwal Kegiatan

\begin{tabular}{|c|c|c|c|c|c|c|}
\hline \multirow[b]{2}{*}{ No } & \multirow[b]{2}{*}{ Jenis Kegiatan } & \multicolumn{5}{|c|}{ Bulan } \\
\hline & & 1 & 2 & 3 & 4 & 5 \\
\hline 1 & $\begin{array}{l}\text { Melakukan Observasi Wilayah dan membangun } \\
\text { kesepahaman dalam kerja sama pengabdian }\end{array}$ & & & & & \\
\hline 2 & $\begin{array}{l}\text { Melakukan Identifikasi Sasaran pelatihan yaitu } \\
\text { Ibu Rumah Tangga yang memiliki anak } \\
\text { Balita,kanak-kanak,anak-anak dan Remaja }\end{array}$ & & & & & \\
\hline 3 & $\begin{array}{l}\text { Melakukan Kesepakatan dengan Warga Sasaran } \\
\text { Mengenai Pelaksanaan pelatihan Parenting } \\
\text { berbasis Refleksi dan Karakter }\end{array}$ & & & & & \\
\hline 4 & Melakukan Observasi Pelatihan & & & & & \\
\hline 5 & $\begin{array}{l}\text { Menghimpun Data; yang meliputi Kekeliruan } \\
\text { yang dilakukan dalam pengasuhan } \\
\text { Menumakan Solusi dari masalah yang dihadapi } \\
\text { Mengambil Makna dari peristiwa yang dialami }\end{array}$ & & & & & \\
\hline 6 & $\begin{array}{l}\text { Memberikan Penguatan hasil Pelatihan pada } \\
\text { waktu Pendampingan }\end{array}$ & & & & & \\
\hline
\end{tabular}

